\title{
Pembelajaran Fisika Berbantuan Quipper School Sebagai Media Pembelajaran
}

\author{
Anggun Variasi Islami ${ }^{1}$, Muhammad Abdurrahman Sunni ${ }^{2}$ \\ Universitas Teknologi Mataran ${ }^{1,2}$ \\ variasi.anggun@gmail.com
}

\begin{abstract}
Abstrak - Penelitian ini bertujuan untuk meningkatkan prestasi belajar siswa pada materi gerak lurus dengan menggunkana media belajar Quipper School. Sebelumnya peneliti mendapatkan kurangnya minat siswa dalam mengulang materi pembelajaran dirumah secara manual sehingga prestasi belajar siswa menjadi rendah. Pada penelitian ini digunakan metode Penelitian Tindakan kelas melalui Best Practice dimana guru dan peneliti menceritakan pengalaman terbaik dalam menyelesaikan suatu permasalahan yang dihadapi oleh pendidik dan tenaga kependidikan sehingga mampu memperbaiki mutu layanan pendidikan dan pembelajaran. Penggunaan Quipper School sebagai media pembelajaran mampu meningkatkan prenstasi belajar siswa. Terlihat dari hasil tes pada siklus kedua yang mengalami peningkatan pada prestasi belajar dengan tingkat ketuntasan hingga $94,42 \%$ sedangkan pada siklus sebelumnya hanya $74,82 \%$. Selain prestasi belajar, Quipper School juga dapat meningkatkan kemandirian siswa dalam belajar.
\end{abstract}

Kata kunci: Quipper School, Prestasi Belajar

\begin{abstract}
This study aims to improve student achievement in straight-motion material using the Quipper School as a media. Previously, researchers found that there was a lack of student interest in repeating learning material at home manually so that student learning achievement was low. In this study the Classroom Action Research method is used through Best Practice in which the teacher and researcher tell the best experience in solving a problem faced by educators and education personnel so as to improve the quality of education and learning services. The use of Quipper School as a learning medium is able to increase student learning achievement. It can be seen from the results of tests in the second cycle that have increased in learning achievement with a mastery level of up to $94.42 \%$ while in the previous cycle only $74.82 \%$. In addition to learning achievement, Quipper School can also improve students' independence in learning.
\end{abstract}

Keyword : Quipper School, student achievement

\section{Latar Belakang}

Berdasarkan perkembangan Teknologi informasi dan karakteristik siswa sekarang ini kemudian terjadilah pergeseran konsep dan mekanisme belajar. Konsep dan mekanisme belajar yang kemudian dikenal dengan ELearning yang kemudian menjadikan proses pembelajaran mengalami transformasi hebat dari yang sebelumnya konvensional menjadi digital. Proses belajar secara E-Learning sudah dilakukan secara massif di Negaranegara maju sejak lebih dari 10 tahun yang lalu akan tetapi di Negara berkembang seperti Indonesia baru dilakukan beberapa tahun terakhir.Seperti bebrapa hasil pada Peer Review yang dilakukan oleh American Collage and Universities sejak lebih dari 10tahun yang lalu sudah banyak membahas tentang bagaimana E-Learning dilakukan. Sedangkan di Indonesia pada tahun 2012 Telah dilakukan pengembangan system pembelajaran dengan E-Learning untuk persiapan ujian nasional. Dengan pengembangan tersebut didapatkan bahwa siswa dapat lebih mudah untuk memahami materi dan juga sangat membantu guru untuk terhubung dengan siswa meskipun siswa ada dirumah [4].

Pembelajaran masa kini tidak dapat dijauhkan dari dunia online. karakteristik Siswa pada era 4.0 ini ketika di rumah lebih banyak berinteraksi dengan gadget, hanya sebagian kecil siswa yang masih berminat membaca buku untuk menemani masa senggang. Keadaaan yang demikian sangat disayangkan jka dibiarkan begitu saja. Guru harus membuat inovasi secara berkala seiring dengan perkembangan zaman. Salah satu cara untuk dapat menarik minat belajar siswa adalah dengan memberikan media pembelajaran secara online. Dengan adanya media pembelajaran secara online, siswa bisa memanfaatkan gadget dengan lebih positif. Pemilihan media pembelajaran harus disuaian dengan Karakteristik Peserta didik [3]. Dalam hal ini media haruslah familiar dengan karakteristik peserta didik atau pendidik. Hal ini berarti media pembelajaran harus disesuaikan dengan kebiasan-kebiasan yang

Pembelajaran Fisika Berbantuan Quipper School Sebagai Media Pembelajaran 
dilakukan oleh siswa. Prestasi yang membanggakan, biasanya memiliki sumber daya manusia dan sistem yang mendukung di dalamnya.

Dalam rangka mewujudkan misi pemerintah untuk mencetak generasi muda yang berdaya saing global, diperlukan pendidikan berbasis teknologi (Edutech). Proses pembelajaran tentu tidak dapat hanya dilakukan di area sekolah saja akan tetapi harus dilakukan juga secara mandiri oleh siswa diluar jam sekolah baik untuk pengulangan atau untuk materi baru. Proses belajar mengajar secara mandiri tersebut harus pula di dukung oleh guru melalui media pembelajaran. Pemilihan metode mengajar dan media pembelajaran sangat penting dalam proses belajar mengajar [3] . penggunaan media pembelajaran dalam proses belajar mengajar dapat membangkitkan motivasi dan rangsangan dalam kegiatan proses belajar mengajar dalam hal yang baru dan bahkan membawa pengaruh-pengaruh mental atau psikologis terhadap peserta didik [1]. Berdasarkan karakteristik siswa yang sudah lekat dengan dunia gadget dan media online lainnya tentu media pembelajaran secara E-Learning dirasa sangat tepat. Menghadirkan metode dan sistem pembelajaran baru ke peserta didik dalam bentuk teknologi digital di zaman era digital sekarang, memang bukanlah perkara sulit, karena semakin gampangnya mendapatkan akses ke berbagai media jasa pelayanan.

Dari berbagai media pembelajaran secara ELearning peneliti menggunakan aplikasi Quipper School. Hal tersebut karena aplikasi Quipper School gratis juga lebih mudah dipahami pengaplikasiannya baik oleh guru maupun oleh siswa dibandingkan dengan media pembelajaran yang lain. Penggunaan Quipper School Penggunaan Quipper School mampu menyediakan beragam topik pembelajaran sekaligus soal dalam bentuk tampilan yang menarik. Setelah para siswa mengerjakan serta mengumpulkan tugasnya, sistem penilaian yang tersedia pada platform Quipper School akan melakukan analisis data secara sederhana namun canggih yang akan membantu guru mendapat gambaran yang jelas tentang pencapaian siswa. Quipper School menyediakan kotak pesan yang menjembatani komunikasi antara guru dan siswa. Pesan ini membuat komunikasi yang baik untuk membahas tugas dan pelajaran yang belum dipahami siswa. [3]

\section{Kajian Pustaka Media Pembelajaran}

Media pembelajaran adalah segala sesuatu yang dapat digunakan untuk menyalurkan pesan dan merangsang terjadinya proses belajar pada si pembelajar (siswa). a. Media belajar merupakan bagian dari sumber belajar b. Sumber belajar dapat berupa pesan, orang, bahan, alat, teknik, dan lingkungan. c. Media belajar merupakan kombinasi antara alat (hardware) dan bahan (software).. kriteria yang harus diperhatikan ketika Memilih media pembelajaran harus diperhatikan. Kesalahan pada saat penentuan jenis media yang digunakan akan berdampak pada berbagai aspek, salah satunya prestasi belajar. Ada beberapa kriteria umum yang perlu diperhatikan dalam memilih media yaitu [1]

1. Kesesuaian dengan Tujuan (intructional goals), Perlu dikaji tujuan pembelajaran apa yang ingin dicapai dalam suatu kegiatan pembelajaran. Kemudian bisa dianalisis media apa saja yang cocok guna mencapai tujuan tersebut

2. Kesesuaian dengan Materi Pembelajaran (intructional content), Yaitu bahan atau kajian apa yang diajarkan pada program pembelajaran tersebut. Pertimbangan lainnya dari bahan atau pokok bahasan tersebut sampai sejauh mana keadaan yang harus dicapai, dengan demikian kita bisa mempertimbangankan media apa yang sesuai dengan menyampaikan bahan tersebut.

3. Kesesuaian dengan Karakteristik Pembelajaran atau Peserta didik, Dalam hal ini media haruslah familiar dengan karakteristik peserta didik atau pendidik, yaitu mengkaji sifat-sifat dan ciri-ciri media yang akan digunakan. Hal lainnya karakteristik peserta didik, baik secara kuantitatif (jumlah) ataupun kualitatif (kualitas, ciri dan kebiasaan lain) dari peserta didik terhadap media yang akan digunakan.

4. Kesesuaian dengan Teori, Pemilihan media ini harus didasarkan atas kesesuaian dengan teori. Media yang dipilih bukan karena fanatisme pendidik terhadap suatau media yang dianggap paling bagu, namun didasarkan atas teori yang diangkat dari penelitian dan riset sehingga telah teruji validitasnya. Pemilihan media harus merupakan bagian integral dari keseluruhan proses pembelajaran yang fungsinya untuk meningkatkan efesiensi dan efektivitas pembelajaran.

5. Kesesuaian dengan Gaya Belajar Peserta didik, Kriteria ini didasarkan atas kondisi psikologis peserta didik, bahwa peserta

Pembelajaran Fisika Berbantuan Quipper School Sebagai Media Pembelajaran 
didik belajar dipengaruhi pula oleh gaya belajar peserta didik.

6. Kesesuaian dengan Kondisi Lingkungan, Fasilitas Pendukung, dan Waktu yang Tersedia, Bagaimanapun bagusnya sebuah media apabila tidak didukung oleh fasilitas waktu yang tersedia maka kurang efektif. Media juga terkait dengan user atau penggunaanya dalam hal ini pendidik, jika pendidik tidak memiliki kemampuan untuk menggunakan media tersebut dengan baik maka akan sisa-sia, begitu juga fasilitas lainnya.

Quipper School adalah salah satu media pembelajaran berbasis online yang bersifat open source atau gratis yang dapat diakses oleh siapa saja, dimana saja dan kapan saja oleh guru maupun siswa. Media ini salah satu cara untuk merevolusi proses belajar mengajar dengan memanfaatkan media internet. Quipper School memiliki dua bagian yaitu Q-Link untuk guru dan Q-Lean untuk siswa.

Penggunaan media online seperti Quipper School merupakan sesuatu yang baru untuk siswa sekaligus sangat menarik. Ketertarikan siswa tersebut dapat dimanfaatkan guru sehingga pembelajaran lebih maksimal. Tampilan yang menarik dan contoh-contoh dari materi yang diberikan lebih beragam dari media pembelajaran membuat pembelajaran lebih bermakna.pembelajaran dengan Quipper School dapat meningkatkan prestasi dan motivasi belajar siswa. Hal tersebut relevan dengan hasil penelitian yang berjudul "Pengembangan Learning Management System Quipper School Pada Pembelajaran Materi Sistem Pertahanan Tubuh Untuk Meningkatkan Motivasi dan Hasil Belajar Siswa Kelas XI di SMA Negeri 3 Yogyakarta". Hasil penelitian tersebut menyatakan bahwa Quipper School sangat layak digunakan untuk meningkatkan motivasi dan hasil belajar siswa

Penggunaan Quipper School sebagai media pembelajaran juga dapat meningkatkan kemandirian siswa. Siswa dapat belajar dengan mandiri dirumah masing-masing karena materi yang disajikan sangat lengkap dan menarik serta mudah dipahami. Peningkatan kemandirian siswa tersebut juga sesuai dengan pernyataann pada penelitian yang berjudul "Penggunaan Quipper School Melalui Pendekatan Saintifik Dalam Pembelajaran Matematika Untuk Meningkatkan Hasil Belajar Siswa". [3]. Peningkatan kemandirian siswa juga didukung oleh penelitian yang berjudul Pengaruh Penerapan E-Learning Quipper School terhadap Kemandirian Belajar Siswa di SMA Negeri 109 Jakarta" dimana didapatkan kemandirian siswa juga mengalami peningkatan. [6]

\section{Metode Penelitian}

Pada penelitian ini digunakan metode Penelitian Tindakan kelas melalui Best Practice dimana guru dan peneliti menceritakan pengalaman terbaik dalam menyelesaikan suatu permasalahan yang dihadapi oleh pendidik dan tenaga kependidikan sehingga mampu memperbaiki mutu layanan pendidikan dan pembelajaran.

Sampel penelitian adalah kelas $X$ Multimedia SMK NW Kumbung. Sampel dipilih dengan cara mengecek fasilitas yang dimiliki siswa. Pada kelas sampel seluruh siswa memiliki HP Android dan sebagian besar yang memiliki komputer atau laptop. Sehingga secara fasilitas siswa sudah siap untuk melakukan pembelajarn secara online dari rumah. Penelitian dilakukan pada mata pelajaran Fisika dengan materi Gerak lurus. Penelitian dilakukan sejak bulan agustus sampai dengan September 2019.

Tehnik pengumpulan data dalam penelitian ini dilakukan dengan menggunakan dokumentasi dan tes. Data yang diperoleh kemudian diolah dan dianalisis dengan mengunakan untuk melihat peningkatan tingkat ketuntasan siswa sebelum dan sesudah menggunakan Qupper School.

\section{Hasil Penelitian}

Pelaksanaan penelitian tindakan kelas (PTK) melalui Best Practice ini meliputi beberapa kegiatan antara lain: perencanaan tindakan (planning), pelaksanaan/ pengumpulan fakta (implementation), evaluasi (evaluation), refleksi laporan (refleting) dan tindak lanjut perbaikan. Adapun hasil pembelajaran / tindakan matematika dengan aplikasi quipper school adalah sebagai berikut: a. Perencanaan Tindakan (Planing)

Pada tahapan ini guru dan peneliti berkolaborasi dalam melakukan perencanaan persiapan proses pembelajaran yaitu mengkaji kompetensi dasar dari materi yang akan diteliti. Selanjutnya membuat RPP yang sesuai dengan kurikulum pada Quipper school.

$$
\begin{aligned}
& \text { b. Pelaksanaan/ pengumpulan fakta } \\
& \text { (implementation) } \\
& \text { Pada tahap pelaksanaan, peneliti }
\end{aligned}
$$
melakukan aktivitas pembelajaran sebanyak 2 siklus. Siklus pertama dilakukan dengan menjelaskan Gerak Lurus Beraturan (GLB) dan Gerak Lurus Berubah Beraturan (GLBB) pada lintasan horizontal. Pada tahapan ini

Pembelajaran Fisika Berbantuan Quipper School Sebagai Media Pembelajaran 
siswa belajar tanpa bantuan Quipper School . Kemudian pada siklus kedua dilakukan pada materi GLBB pada lintasan vertikal dan berbantuan Quipper School.

c. Evaluasi (Evaluation)

Sebagian besar siswa sangat tertarik dengan pembelajaran menggunakan Quipper School. Siswa lebih leluasa melihat materi dan contoh pengaplikasian materi gerak lurus secara langsung. Siswa tidak harus mencatat karena siswa bisa mengakses kembali dirumah masing-masing. Pengamatan dilakukan pada kemampuan siswa menjawab soal yang diberikan secara online. soal berupa pilihan ganda yang berkaitan dengan GLBB secara keseluruhan.

Berikut ini ringkasan pencapaian siswa sebelum dan sesudah menggunakan Quiper School

Tabel 1. Prestasi belajar siswa

\begin{tabular}{|c|c|c|c|}
\hline $\begin{array}{l}N \\
0\end{array}$ & Aspek & $\begin{array}{l}\text { Sebelum } \\
\text { QS }\end{array}$ & $\begin{array}{l}\text { Sesudah } \\
\text { QS }\end{array}$ \\
\hline 1 & Nilai Tertinggi & 82 & 100 \\
\hline 2 & Nilai Terendah & 45 & 75 \\
\hline 3 & Nilai Rata-rata & 64,2 & 90,3 \\
\hline 4 & $\begin{array}{l}\text { Jumlah Siswa } \\
\text { Yang tuntas }\end{array}$ & 26 & 33 \\
\hline 5 & $\begin{array}{lr}\text { Jumlah } & \text { siswa } \\
\text { yang } & \text { tidak } \\
\text { tuntas } & \end{array}$ & 9 & 2 \\
\hline 6 & $\begin{array}{l}\text { Tingkat } \\
\text { ketuntasan }\end{array}$ & $74,82 \%$ & $94,42 \%$ \\
\hline
\end{tabular}

\section{d. Refleksi Laporan (Reflection)}

Dari data pada tabel prestasi belajar sebelum dan sesudah menggunakan Quipper School diatas terlihat bahwa tingkat ketuntasan siswa dengan pembelajaran klasikal tanpa bantuan QS hanya 74, $82 \%$ dengan nilai rata-rata sebesar 64,2. Sedangkan pada pembelajaran dengan bantuan QS meningkat menjadi $94,42 \%$ dan rata-rata 90,3. Sehingga peneliti sangat merekomendasikan pembelajaran dengan menggunakan Quipper School.

\section{e. Tindak lanjut perbaikan}

Melihat prestasi belajar yang berubah sangat signifikan tentu saja siswa dan guru dapat terus menggunakan media online seperti Quipper School sebagai bantuan pembelajaran. Guru dapat memberikan Pekerjaan Rumah melalui QS secara kontinu disetiap materi atau melakukan uji kompetensi di setiap materi pada masing-masing mata pelajaran secara online dengan waktu yang sangat tidak terbatas.

\section{Pembahasan}

Penggunaan media pembelajaran yang tepat akan sangat berpengaruh pada prestasi belajar siswa. Oleh karena itu guru atau peneliti harus memahami karakteristik dari siswa dan materi yang akan diajarkan sehingga dapat menentukan media yang tepat yang akan digunakan pada proses belajar mengajar.

Tepatnya penggunaan media pembelajaran berbasis online yang digunakan oleh guru pada penelitian ini berdampak besar pada peningkatan prestasi belajar siswa. Hal tersebut tergambar pada tabel 1. Tingkat ketuntasan siswa naik sebesar $19,20 \%$ dari $74,82 \%$ hingga $94,42 \%$.

Penggunaan Quipper School yang gratis menjadi alternatif yang bagus untuk menfasilitasi guru dan siswa. Video-video pembelajaran yang disajikan pun sangat menarik sehingga minat belajar siswa meningkat. Pembelajaran berbasis online bagi siswa pada SMK NW Kumbung adalah hal baru. Hal tersebut menyebabkan siswa memiliki Ketertarikan yang sangat besar terhadap pembelajaran online. Pembelajaran online menggunakan Quipper school mampu menumbuhkan kemandirian siswa yang sebelumnya hanya menunggu materi yang disampaikan oleh guru.

Siswa juga mengungkapkan keinginannya untuk tetap menggunakan Quipper School pada materi selanjutnya. Dampak baik yang dihasilkan berupa prestasi belajar mereka yang meningkat membuahkan feedback yang bagus. Siswa berkeinginan untuk tetap difasilitasi oleh guru.

Minat belajar siswa menggunakan Quipper School juga ditularkan kepada kelas yang belum menggunakan Quipper School. Hal tersebut diungkapkan siswa kepada guru disela-sela pelajaran. Akan tetapi berbagai pertimbangan membuat guru belum bisa menerapkan secara menyeluruh. Salah satu alasannya adalah kurangnya fasilitas yang dimiliki siswa. Sebagian siswa tidak memiliki HP android dan atau laptop sehingga sudah tentu akan berdampak pada kurang meratanya proses belajar-mengajar pada kelas tersebut.

Kelebihan dari penggunaan Quipper

School adalah:

a. Guru dapat mengamati aktivitas siswa,

melihat dan mengenali siswa dari sisi

tanggung jawab, sportifitas, dan kejujuran.

b. Guru dapat mengetahui berapa menit

siswa mengerjakan soal, jadi guru tahu

apakah siswa membaca materinya atau

Pembelajaran Fisika Berbantuan Quipper School Sebagai Media Pembelajaran 
tidak, jadi guru juga tahu pada materi apa

siswa kurang mengerti.

c. Antar guru diseluruh Indonesia yang

menggunakan QS pun dapat saling

mengenal sehingga dapat saling bertukar

pikiran mengenai masalah ataupun kendala

yang dihadapi ketika mengajar di sekolah

masing-masing.

\section{Pustaka}

[1] Arsyad, Azhar. 2013. Media Pembelajaran. Depok: PT RAJAGRAFINDO PERSADA

[2] Nurhasnawati (2011) Media Pembelajaran.

Pekanbaru,Pusaka Riau

[3] Rahmiati dan Pianda, Didi.2018. penggunaan quipper school melalui pendekatan saintifik dalam pembelajaran matematika untuk meningkatkan hasil belajar siswa. Jurnal Mitra Pendidikan. Vol 2, No. 2

[4] Sriwihajriyah, Nyimas dkk. 2012. Sistem Pembelajaran Dengan E-Learning Untuk Persiapan Ujian Nasional Pada Sma Pusri Palembang. Jurnal Sistem Informasi (JSI),VOL. 4, NO.1

[5] Tim Pengembang Quipper School. (2014). QuipperSchool.

http://indonesia.quipperschool.com/ pada mei 2019 jam 23.10 wita

[6] Trisnaningsih, Sari. 2016. Pengembangan Learning Management System Quipper School Pada Pembelajaran Materi Sistem Pertahanan Tubuh Untuk Meningkatkan Motivasi Dan Hasil Belajar Siswa Kelas XI Di SMA Negeri 3 Yogyakarta. Jurnal Pendidikan Biologi Volume 5 Nomor 6 Tahun 2016 diakses April 2019.

[7] Uma, E. R. 2015. Pemanfaatan Quipper School di Kalangan Siswa SMA (Studi Deskriptif tentang Pemanfaatan Quipper School sebagai Media Pendukung Belajar Siswa di Madrasah Aliyah 